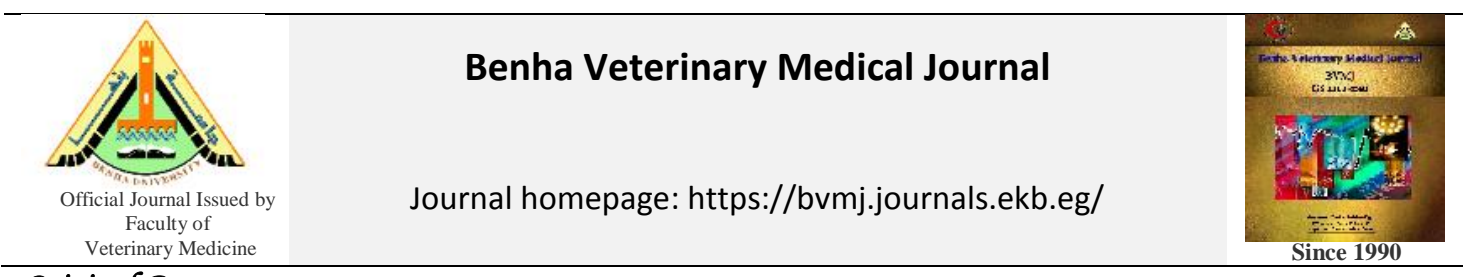

Original Paper

\title{
Chemical quality of some freshwater fish in Egyptian markets
}

\author{
Hemmat M. Ibrahim¹, Mohamed A. Hassan', Reham A. Amin1, Omayma M.A.L. Maghraby², Ahmed \\ Mohammed Mostafa ${ }^{2, *}$ \\ ${ }^{1}$ Food Control Dept., Fac. Vet. Med., Benha University. \\ ${ }^{2}$ Food Hygiene Dept., Animal Health research Institute, Dokki
}

\section{ARTICLE INFO}

\begin{tabular}{l}
\hline Keywords \\
Bagrus bayad. \\
$p H$ \\
$T B A$ \\
$T M A$ \\
TVB-N \\
Received 17/08/2020 \\
Accepted 12/09/2020 \\
Available On-Line \\
01/10/2020
\end{tabular}

\begin{abstract}
Total ninety random meat samples of fresh fish of Nile tilapia, Bagrus bayad and Clarias gariepinus (thirty of each) were collected from different Egyptian fish markets to be examined for their chemical quality indices to determine their fitness for human consumption. The results showed that the $\mathrm{pH}$ value was $(6.32 \pm 0.01,6.38 \pm 0.02$ and $6.29 \pm 0.02)$, TVB-N (mg/100) was $(14.54 \pm 0.51,12.71 \pm 0.43$ and $16.76 \pm 0.46)$, TBA (mg $\mathrm{MDA} / \mathrm{kg})$ was $(0.82 \pm 0.05,0.57 \pm 0.03$ and $0.91 \pm 0.06)$ and TMA $(\mathrm{mg} / 100)$ was $(6.19 \pm 0.23$, $5.49 \pm 0.21$ and 6.75 \pm 0.19 ) in the examined samples of Nile tilapia, Bagrus bayad and Clarias gariepinus, respectively. So, it was appeared that the Clarias gariepinus samples were higher in their $\mathrm{pH}$, TVB-N, TMA, TBA values than other examined samples. All examined samples were fit for human consumption except one Clarias gariepinus sample $(3.33 \%)$ was unfit due to increasing its $\mathrm{pH}$ value than the limit of acceptability. This study shows superiority of Bagrus bayad were more than Nile tilapia followed by Clarias gariepinus samples in their chemical quality indices. So, we recommend proper handling of fish from catching till eating to preserve their human consumption fitness
\end{abstract}

\section{INTRODUCTION}

Fish being from the most important foods due to its nutritional qualities, where it is a good source of highquality protein those containing essential amino acids that required for good nutrition. Also, fish provides a good source of minerals and vitamins (Onyia et al. 2013).

Fish is one of the perishable foods .So, because of globalization of trade of food, fish products tend to rejection because of poor quality (Huss et al., 2004). For this reason, the fish and fishery products quality become of a high concern in fish industry. (Huss et al., 2003).

The different methods frequently used for fish spoilage assessment were classified into 2 types: sensory methods and instrumental (physical, microbiological and biochemical) methods (Huss, 1995).

The chemical quality indices more used to examine fish quality deterioration consist of TMA and TVB-N (Howgate, 2009). Breakdown of fish protein content and fat content (agent of off-flavor and rancidity) leads to quick spoilage of fish (Daramola et al., 2007).

$\mathrm{pH}$ was a indicators of the freshness of fish because it start with low value at the storage early stage that means the nutritional condition was even now good and then increase in its value when the fish storage continue. (Abbas et al., 2008). This, increasing is caused by accumulation of alkaline material (TMA and TVB-N).

Total volatile basic nitrogen is an important parameter for the quality determination in seafood products and it is the most popular chemical indicators for spoilage of fish. Also, it has close relationship with bacterial counts and sensory score (Amegovu et al., 2012). Total volatile basic nitrogen consists of volatile amines as, dimethylamine, trimethylamine and ammonia that produced by spoilage bacteria. And the total volatile basic nitrogen produced by autolytic enzymes during frozen storage of fish (Teklemariam, 2015). So, it is indicator of bacterial spoilage and it's increasing than permissible limit make the fish unsafe for human consumption.

Trimethylamine oxide being from the components of nonprotein nitrogen (NPN) that used for assessing of fish shelf life and freshness. (Huss and Larsen, 1980). TMA was formed by Post-mortem bacterial degradation of trimethylamine oxide (TMAO). Volatile amines accumulation plays a higher role in the fish products quality loss due to the unpleasant odors that is combined with the products degradation. Increasing of the TMA content leads to increasing in the TVB-N content during spoilage (Jinadasa, 2014).

Fish lipids contain very high polyunsaturated fatty acids amount that are susceptible to oxidative rancidity. During the fish storage, fish lipid oxidation and hydrolysis occurred. This was lead to prevention of the fish acceptance for human consumption as a result of influencing rancidity development, texture changes, and protein denaturation (Verma et al. 1995). Lipid oxidation is a major cause of many problems that decrease the fish product shelf-life. It was lead to texture and color changes as well as rancid odor and off-flavor. Thiobarbituric acid test based on the reaction of TBA reagent with

\footnotetext{
* Corresponding author: Ahmed Mohammed Mostafa*, Food Hygiene Dept., Animal Health research Institute, Dokki dr_ahmed_gado64@yahoo.com
} 
malonaldehyde for obtaining a red color, that formed due to the condensation of 2TBA molecules with a molecule of malonaldehyde and the likely elimination of 2 molecules of water (Fernandez et al., 1997). And it is indication for oxidative rancidity. Malondialdehyde is the lipid oxidation major product have carcinogenic and genotoxic effect (Hartman, 1983).

The maximum permissible limit of TVB-N, TBA, TMA, $\mathrm{pH}$ value in fresh and chilled fish was $30 \mathrm{mg} / 100 \mathrm{~g}, 4.5 \mathrm{mg}$ $\mathrm{MAD} / \mathrm{kg}, 10 \mathrm{mg} / 100 \mathrm{~g}$ and 6.5 (E.S, 2005). Bacterial contamination during handling of fish make breakdown of fish tissue that leads to increasing in the values of chemical quality indicators than its permissible limits. So, fish become unfit for human consumption.

The present study aimed to determine the fitness of some freshwater fish in Egyptian markets for human consumption based on their chemical quality indices

\section{MATERIAL AND METHODS}

\subsection{Samples}

\subsection{Samples collection:}

Ninety random meat samples of fresh fish of Nile tilapia, Bagrus bayad and Clarias gariepinus (30 of each) were collected from different Egyptian fish markets located in El- Kalubia, Cairo and Giza governorates. Each sample was kept and transferred to the laboratory as quickly as possible in an insulated ice box. And then, the collected samples subjected to the chemical examinations to evaluate the fish quality indices of the fish species.

\subsection{Chemical quality indices:}

2.2.1. $p H$ (E.S., 2017).

$10 \mathrm{~g}$ of homogenized fresh water fish samples was added in $100 \mathrm{ml}$ of pre boiled cooled distilled water at $25^{\circ} \mathrm{C}$ and checked for $30 \mathrm{~min}$ and was leaved on aside for $10 \mathrm{~min}$ then, apart from aqueous layer was added to a beaker and $\mathrm{pH}$ was measured by $\mathrm{pH}$ meter that was previously calibrated using standard buffers of $\mathrm{pH} 4$ and 7 at room temperature.

\subsubsection{Total volatile basic nitrogen (TVB-N) determination} (E.S., 2017).

Nearly 10 gram of previously prepared and homogenized fish sample was put on a conical flask with $300 \mathrm{~mL}$ of D.W. Then, $2 \mathrm{~g}$ of magnesium oxide was added followed by antifoaming agent as some glass beads. The distillate was received in Erlenmeyer flask containing $25 \mathrm{~mL}$ of boric acid solution (2\%) until the final distillate reach 125 $\mathrm{mL}$ in its volume. Titration of the distillate was occurred by using $\mathrm{H}_{2} \mathrm{SO}_{4}$ solution $(0.1 \mathrm{~N})$ till the natural red end point. The same procedures were occurred by using D.W instead of the samples for blank detection. TVB-N (mg N/100g) of fish flesh was calculated as follows:

TVB-N $(\mathrm{mg} \mathrm{N} / 100 \mathrm{~g})=(\mathrm{S}-\mathrm{B}) \times 14$

Where: $\mathrm{S}=\mathrm{H}_{2} \mathrm{SO}_{4}$ volume that was used for sample titration, and $\mathrm{B}=$ volume of $\mathrm{H}_{2} \mathrm{SO}_{4}$, that was titrated for blank

2.2.3. Trimethylamine (TMA) determination (E.S., 2017). $200 \mathrm{ml}$ of TCA solution $(7.5 \%)$ was added to $100 \mathrm{~g}$ of minced fish meat then mixed well and centrifuged at 3000 rpm till the clear supernatant was obtained. $1 \mathrm{ml}$ of sample supernatant and $3 \mathrm{~mL}$ of D.W was added to a test tube. On another 3 test tubes $1 \mathrm{ml}, 2 \mathrm{ml}$ and $3 \mathrm{ml}$ of TMA standard solution was added and completed to $4 \mathrm{ml}$ by D.W. On the blank test tube, we added $4 \mathrm{ml}$ of D.W. In all test tubes $1 \mathrm{ml}$ formaldehyde solution $(20 \%), 10 \mathrm{~mL}$ toluene and 3 $\mathrm{mL}$ potassium carbonate solution were added then the test tubes were shacked vigorously. $8 \mathrm{~mL}$ of the toluene layer was put on $0.1 \mathrm{ml}$ anhydrous sodium sulfate then shacked for toluene dehydration. On a test tube $5 \mathrm{ml}$ from the dehydrated toluene layer was mixed with $5 \mathrm{~mL}$ of picric acid solution. After that, the optical density was measured photometrically by spectrophotometer at $410 \mathrm{~nm}$ wavelength.

Calculation: TMA (mg /100g) $=\mathrm{D} \times \mathrm{Wt} . \times \mathrm{V} \times 300 / \mathrm{A}$

Where: $\mathrm{D}=$ sample absorbance, Wt. = mg of TMA-N $/ \mathrm{ml}$ standard solution, $\mathrm{V}=\mathrm{ml}$ of used standard solution; $300=$ approximation total supernatant $(\mathrm{ml})(200 \mathrm{ml}+100 \mathrm{~g})$, and $\mathrm{A}=$ standard absorbance nearest to sample absorbance.

\subsubsection{Thiobarbituric acid (TBA) determination (E.S.,} 2017).

Approximately, ten grams of prepared fish sample was mixed with distilled water, $\mathrm{HCl}$ solution $(4 \mathrm{~N})$ and Antipumping stones in a distilling flask. The distillation was done till collection of $50 \mathrm{ml}$ distillate on an empty flask. 5 $\mathrm{ml}$ distillate was mixed with $5 \mathrm{ml}$ TBA reagent in attest tube that was put for $35 \mathrm{~min}$ into boiling water bath. The blank was done by using $5 \mathrm{ml}$ D.W instead of sample with the $5 \mathrm{ml}$ of TBA reagent. The sample optical density (D) was read at a wavelength of $538 \mathrm{~nm}$ against the blank on the spectrophotometer.

Calculation: TBA $(\mathrm{mg}$ MDA $/ \mathrm{kg})=\mathrm{D} \times 7.8$

\section{RESULTS}

From the results presented in table (1),it was appeared that the $\mathrm{pH}$ value of the examined Nile tilapia, Bagrus bayad and Clarias gariepinus samples were varied from (6.15 to $6.32,6.08$ to 6.48 and 6.22 to 6.67 ), respectively.

Table 1 Statistical analysis of $\mathrm{pH}$ values in the examined freshwater fish samples $(n=30)$.

\begin{tabular}{lcccc}
\hline Fish samples & Nile tilapia & Clarias gariepinus & Bagrus bayad \\
\hline Min. & 6.15 & 6.22 & 6.08 \\
Max. & 6.49 & 6.67 & 6.48 \\
Mean \pm SE. & $6.32 \pm 0.01^{\mathrm{A}}$ & $6.38 \pm 0.02^{\mathrm{B}}$ & $6.29 \pm 0.02^{\mathrm{A}}$ \\
Max. Per. Limit & & 6.5 & 6.5 & 6.5 \\
\hline \multirow{2}{*}{ Accepted samples } & NO. & 30 & 29 & 30 \\
& $\%$ & 100 & 96.67 & 100 \\
\hline There are sig. diff. & $(\mathrm{P}<0.05)$ & between means &
\end{tabular}
According to E.S (2005). F value $=7.55$

Results presented in table (2) revealed that the TVB-N value of the examined Nile tilapia, Bagrus bayad and Clarias gariepinus samples were varied from (7.28 to $18.48,8.68$ to 17.92 and 11.76 to 21.28$) \mathrm{mg} \mathrm{N} / 100 \mathrm{~g}$ with an average of $(14.54 \pm 0.51,12.71 \pm 0.43$ and $16.76 \pm 0.46) \mathrm{mg}$ $\mathrm{N} / 100 \mathrm{~g}$, respectively.

Table 2 Statistical analysis of TVB-N $(\mathrm{mg} / 100 \mathrm{~g})$ in the examined samples of freshwater fish $(n=30)$.

\begin{tabular}{lcccc}
\hline Fish samples & Nile tilapia & Clarias gariepinus & Bagrus bayad \\
\hline Min. & 7.28 & 11.76 & 8.68 \\
Max. & 18.48 & 21.28 & 17.92 \\
Mean \pm SE. & $14.54 \pm 0.51^{\mathrm{A}}$ & $16.76 \pm 0.46^{\mathrm{B}}$ & $12.71 \pm 0.43^{\mathrm{C}}$ \\
Max. Per. Limit $(\mathrm{mg} / 100 \mathrm{~g}) *$ & 30 & 30 & 30 \\
\hline \multirow{2}{*}{ Accepted samples } & NO. & 30 & 30 & 30 \\
& $\%$ & 100 & 100 & 100 \\
\hline \multicolumn{2}{l}{ There are sig. diff. $(\mathrm{P}<0.05)$} & between means & having the different capital letters. ${ }^{*}$
\end{tabular}

According to E.S. (2005). $\mathrm{F}$ value $=18.846$ 
Table (3) showed that the TMA (mg N/100g) value of the examined samples was varied from (2.69 to 8.23) with an average of $6.19 \pm 0.23$ in Nile tilapia, varied from (4.20 to $8.74)$ with an average of $6.75 \pm 0.19$ in Clarias gariepinus

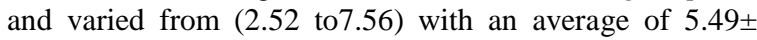
0.21 in Bagrus bayad.

Table 3 Statistical analysis of TMA (mg/100g) in the examined fish samples of fresh water sources $(\mathrm{n}=30)$.

\begin{tabular}{|c|c|c|c|c|}
\hline \multicolumn{2}{|l|}{ Fish samples } & Nile tilapia & Clarias gariepinus & Bagrus bayad \\
\hline \multicolumn{2}{|l|}{ Min. } & 2.69 & 4.20 & 2.52 \\
\hline \multicolumn{2}{|l|}{ Max. } & 8.23 & 8.74 & 7.56 \\
\hline \multicolumn{2}{|l|}{ Mean \pm SE. } & $6.19 \pm 0.23^{\mathrm{A}}$ & $6.75 \pm 0.19^{\mathrm{A}}$ & $5.49 \pm 0.21^{\mathrm{B}}$ \\
\hline \multicolumn{2}{|c|}{ Max. Per. Limit (mg/100g)* } & 10 & 10 & 10 \\
\hline \multirow{2}{*}{ Accepted samples } & NO. & 30 & 30 & 30 \\
\hline & $\%$ & 100 & 100 & 100 \\
\hline
\end{tabular}

letters. * According to E.S. (2005). F value $=8.615$

From the results recorded in table (4) it is evident that the TBA (mg Malondialdehyde/ $\mathrm{kg}$ ) varied from 0.42 to 1.48 with an average of $0.82 \pm 0.05$ in examined Nile tilapia samples, 0.53 to 1.70 with an average of $0.91 \pm 0.06$ in examined Clarias gariepinus samples and 0.36 to1.07 with an average of $0.57 \pm 0.03$ in examined Bagrus bayad samples.

Table 4 Statistical analysis of TBA (mg Malondialdehyde $/ \mathrm{kg}$ ) in the examined samples of freshwater fish $(n=30)$.

\begin{tabular}{lcccc}
\hline Fish samples & Nile tilapia & $\begin{array}{c}\text { Clarias } \\
\text { gariepinus }\end{array}$ & Bagrus bayad \\
\hline Min. & 0.42 & 0.53 & 0.36 \\
Max. & 1.48 & 1.70 & 1.07 \\
Mean \pm SE. & $0.82 \pm 0.05^{\mathrm{A}}$ & $0.91 \pm 0.06^{\mathrm{A}}$ & $0.57 \pm 0.03^{\mathrm{B}}$ \\
Max. Per. Limit (mg MDA $/ \mathrm{kg}) *$ & 4.5 & 4.5 & 4.5 \\
\hline \multirow{2}{*}{ Accepted samples } & NO. & 30 & 30 & 30 \\
& $\%$ & 100 & 100 & 100 \\
\hline There are sig.
\end{tabular}

There are sig. diff. $(\mathrm{P}<0.05)$ between means having the different capital letters. * According to E.S. (2005). $\mathrm{F}$ value $=13.152$

\section{DISCUSSION}

Chemical quality indicators as (TBA, TMA and TVB-N) were used for evaluation of fish quality (El-Marrakchi et al., 1990). In this research, 3 types of freshwater fish (Nile tilapia, Bagrus bayad and Clarias gariepinus) were examined for determining their indices of chemical quality and their human consumption safety.

The $\mathrm{pH}$ is a remarkable intrinsic parameter related to fish meat and affect the freshness as, its affection by bacterial growth (Gram and Huss, 1996). Results obtained in table (1) were appeared that the mean $\mathrm{pH}$ values were $6.32 \pm 0.01$ in Nile tilapia was lowered than6.38 \pm 0.02 that's of Clarias gariepinus and was higher than $6.29 \pm 0.02$ that's of Bagrus bayad. This results was nearly similar to results recorded by Alparslan et al. (2013) $(6.35 \pm 0.02)$ in raw sea bass, Ghannam et al. (2015) $(6.32 \pm 0.01$ and $6.25 \pm 0.02)$ in catfish during winter and spring seasons, respectively and Gonçalves et al. (2018) reported that the initial $\mathrm{pH}$ of the fish sample was 6.4.Higher result obtained by Khidhir et al. (2013) (from 6.757 to 7.908), Ghannam et al. (2015) (from $6.85 \pm 0.01$ to $7.11 \pm 0.02$ ) in Nile tilapia and Gerges, et al., (2016) $(6.5 \pm 0.02)$ in control Nile tilapia fillet at 0 day of examination. Lower result obtained by Gamal El-Deen and El-Shamery (2010) (from 5.3 to 5.7) and Alparslan et al. (2013) (4.32 \pm 0.04$)$ in scaly Marinated sea bass. There were significant differences among examined (Nile tilapia and Clarias gariepinus) and (Clarias gariepinus and Bagrus bayad ) samples $(\mathrm{P}<0.05)$. Differences of $\mathrm{pH}$ values were affected by differences in the diet, species, seasons, type of muscle and the stress level during fish catching or due to different bacterial contamination levels which lead to formation of different levels of alkaline metabolites as TVB-N and TMA. There were no significant differences $(\mathrm{P}>0.05)$ among examined (Nile tilapia and Bagrus bayad) samples. All examined samples were accepted in $\mathrm{pH}$ value according to "E.S" (2005) except one Clarias gariepinus sample $(3.33 \%)$ was unaccepted.

TVB-N being, a perfect indicator for determination of the freshness and quality measurement in Nile Tilapia and African catfish (Liu et al., 2010). The results recorded in table (2) was appeared that the TVB-N value (mg N/100g) of the examined samples of Nile tilapia $(14.54 \pm 0.51)$ was lower than that of Clarias gariepinus $(16.76 \pm 0.46)$ and was higher than that of Bagrus bayad (12.71 \pm 0.43$)$. This result was nearly similar to results obtained by Alparslan et al., (2013) $(16.89 \pm 1.45 \mathrm{mg} / 100 \mathrm{~g})$ in raw sea bass, Ghannam et al., (2015) $(16.01 \pm 0.14 \mathrm{mg} / 100 \mathrm{~g}$ in Nile tilapia during winter season) and Hassan et al., (2019) who recorded TVB-N was $12.31 \pm 1.14 \mathrm{mg} / 100 \mathrm{~g}$ in Clarias gariepinus samples. Higher result obtained by Jianadasa et al., (2014) (52 in mg/100g sailfish), Ghannam et al., (2015) $(19.27 \pm 0.19 \mathrm{mg} / 100 \mathrm{~g}$ in catfish during summer season) and Enenwa et al., (2019) (21.95 to $55.44 \mathrm{mg} / 100 \mathrm{~g}$ in Trachurus trachurus samples). Lower result obtained by, Alparslan et al., (2013) $(9.82 \pm 0.87 \mathrm{mg} / 100 \mathrm{~g}$ in scaly Marinated sea bass), Enenwa et al., (2019) (8.78 to 9.47) $\mathrm{mg} / 100 \mathrm{~g}$ in Clupea harengus, and Hassan et al., (2019) $(6.84 \pm 0.52$ and $8.97 \pm 0.69) \mathrm{mg} / 100 \mathrm{~g}$ in $M$. cephalus and $O$. niloticus samples, respectively. There were significant differences among different species of examined samples $(\mathrm{P}<0.05)$. This was caused by different count of bacterial contamination from environment or improper handling and preservation that lead to protein degradation and releasing the TVB-N. TVB-N was good seafood advanced spoilage chemical indicator, but it was an insufficient as quality sign for seafood initial stages of spoilage (Tejada and Huidobro, 2002). All examined samples $(100 \%)$ were accepted in TVB-N according to "E.S" (2005).

Tri-methylamine originates from bacterial decomposition therefore, it was considered as an indicator for bacterial growth (Jianadasa et al., 2014). It was answerable for fishy flavor and odor that was appeared after several days from fish catching (Etienne et al., 2005).Results obtained in table (3) was revealed that TMA (mg/100g) content was higher in Clarias gariepinus than Nile tilapia followed by Bagrus bayad. Nearly similar results were recorded by Enenwa et al., (2019) $\left(6.55 \mathrm{mg} / 100 \mathrm{~g}\right.$ in $1^{\text {st }}$ collection of Sardina pilchardus) and Hassan et al., (2019) $5.70 \pm 0.43 \mathrm{mg} / 100 \mathrm{~g}$ in Clarias gariepinus. Higher result reported by Dergal et al., (2013) $(8.49 \pm 0.43 \mathrm{mg} / 100 \mathrm{~g})$ in refrigerated Nile tilapia and Enenwa et al., (2019) (20.77 and 40.67) $\mathrm{mg} / 100 \mathrm{~g}$ in $1^{\text {st }}$ and $2^{\text {nd }}$ Collection of Trachurus trachurus samples, respectively. Lower result obtained by Alparslan et al., (2013) (ranged from $2.86 \pm 0.1$ to $3.21 \pm 0.12$ ) $\mathrm{mg} / 100 \mathrm{~g}$, Dergal et al., (2013) $(0.65 \pm 0.16 \mathrm{mg} / 100 \mathrm{~g})$ in fresh Nile tilapia, Ghannam et al., (2015) (varied from $0.45 \pm 0.02$ to $0.95 \pm 0.05) \mathrm{mg} / 100 \mathrm{~g}$, Enenwa et al., (2019) (3.37 and 1.39$) \mathrm{mg} / 100 \mathrm{~g}$ in $2^{\text {nd }}$ and $3^{\text {rd }}$ Collection of Sardina pilchardus, and Hassan et al., (2019) (2.26 \pm 0.19 $\mathrm{mg} / 100 \mathrm{~g}$ for $M$. cephalus and $3.54 \pm 0.26 \mathrm{mg} / 100 \mathrm{~g}$ for $O$. niloticus) samples. There were significant differences $(\mathrm{P}<0.05)$ among examined (Nile tilapia and Bagrus bayad) samples and between the examined (Clarias gariepinus and 
Bagrus bayad) samples. TVB-N and TMA were affected by the activity of spoilage bacteria and the effect of endogenous enzymes (Kilinc and Cakli, 2004). There were no significant differences $(\mathrm{P}>0.05)$ among examined (Nile tilapia and clarias gariepinus) samples. All examined samples were accepted in TMA according to "E.S" (2005). The TBA value was widely used in fish and fish products for measuring lipid oxidation (Yanar et al., 2006). And it was responsible for off odor, rancid flavor, texture as well as color deterioration (Olafsdottir et al., 1997). It is evident from the results recorded in table (4) that the TBA values (mg Malondialdehyde/kg) were lower in Bagrus bayad than Nile tilapia than Clarias gariepinus examined samples. The TBA results in the examined samples were nearly similar to those obtained by Ghannam et al., (2015) (from $0.50 \pm 0.05$ to $0.80 \pm 0.01$ ) $\mathrm{mg}$ Malondialdehyde $/ \mathrm{kg}$ in Nile tilapia and Enenwa et al., (2019) (0.5 and 0.9) mg Malondialdehyde/ $\mathrm{kg}$ in $1^{\text {st }}$ and $2^{\text {nd }}$ Collection of Clupea harengus, respectively. Lower results were obtained by Alparslan et al., (2013) $(0.30 \pm 0.01 \mathrm{mg} \mathrm{MDA} / \mathrm{kg})$ in raw sea bass, Ghannam et al., (2015) $(0.40 \pm 0.04$ and $0.45 \pm 0.02) \mathrm{mg} \mathrm{MDA} / \mathrm{kg}$ in catfish during winter and spring seasons, respectively and Enenwa et al., (2019) (0.39 mg $\mathrm{MDA} / \mathrm{kg}$ ) in $3^{\text {rd }}$ collection of Clupea harengus. Higher result were reported by Alparslan et al., (2013) (7.83 \pm 0.06 mg MDA $/ \mathrm{kg}$ ) in scaly Marinated sea bass, Enenwa et al., (2019) (from 2.82 to 4.00) $\mathrm{mg} \mathrm{MDA} / \mathrm{kg}$ in Trachurus trachurus and Hassan et al., (2019) (3.16 $\pm 0.22 \mathrm{mg}$ $\mathrm{MDA} / \mathrm{kg}$ ) in Oreochromis niloticus. There were significant differences $(\mathrm{P}<0.05)$ among examined (Nile tilapia and Bagrus bayad) samples and between the examined (Clarias gariepinus and Bagrus bayad) samples, but There were no significant differences $(\mathrm{P}>0.05)$ among examined (Nile tilapia and Clarias gariepinus) samples. This may be explained by different handling or storage or preservation or species or environment where in the most of aquaculture ponds the Nile tilapia and clarias gariepinus were reared together. All examined samples were accepted in TBA according to "E.S" (2005).

\section{CONCULSION}

There was a superiority of Bagrus bayad than Nile tilapia followed by Clarias gariepinus samples in their chemical quality indices. All examined fish samples were fit for human consumption according to the chemical quality. Proper handling, preservation, sailing and processing are recommended for the preservation of the fish quality.

\section{REFERENCES}

1. Abbas, K.A., Mohamed, A., Jamilah, B. and Ebrahimian, M. 2008. A Review on Correlations between Fish Freshness and $\mathrm{pH}$ during Cold Storage. American Journal of Biochemistry and Biotechnology, 4: 416-421

2. Alparslan, Y., Baygar, T., Hasanhocaoğlu, H. and Metin, C. 2013. Effects of scale and skin on chemical and sensory quality of marinated sea bass filets (Dicentrarchuslabrax, L. 1758 ) in sunflower oil during storage at $4^{\circ} \mathrm{C}$.Emir. J. Food Agric., 25 (7): 516-523

3. Amegovu, A. K., Sserunjogi, M. L., Ogwok, P. and Makokha, V. 2012. Nucleotited degradation products, total volatile basic nitrogen, sensory and microbiological quality of nile pearch (Lates niloticus) fillets under chilled storage. Journal of Microbiology, Biotechnology and Food Sciences 2: $653-666$

4. Daramola, J.A., Fasakin, E.A. and Adeparusi, E.O. 2007. Changes in physicochemical and sensory characteristics of smoke-dried fish species stored at ambient temperature. African Journal of Food, Agriculture, Nutrition and Development, 7(6):1684-5358.

5. Dergal, N. B., Abi-Ayad, S. M. E. A., Degand, G., Douny, C., Brose, F., Daube, G., Rodrigues, A. and Scippo, M. L. 2013. Microbial, biochemical and sensorial quality assessment of Algerian farmed tilapia (Oreochromis niloticus) stored at 4 and $30^{\circ} \mathrm{C}$. Afr. J. Food Sci., 7 (12): 498507

6. E.S., 2005. Egyptian Standard chilled fish (3494/2005) Egyptian Organization for Standardization (EOS), Arab Republic of Egypt.

7. E.S., 2017. Physical and chemical methods for testing fish and fishery products Part: 1 Frozen Fish, ES: 2760-1/ 2006. Egyptian Organization for Standardization (EOS), Arab Republic of Egypt.

8. El-Marrakchi, A., Bennour, M., Bouchriti, N., Hamama, A. and Tagafait, H.1990. Sensory, chemical, and microbiological assessment of Moroccan sardines (Sardina pilchardus) stored in ice. Journal of Food Protection, 53: 600-605.

9. Enenwa A.A., Suleiman, B. and Abolude, D.S., 2019. Biochemical qualities of three imported frozen fish species sold in Zaria, Nigeria. International Journal of Fisheries and Aquatic Studies, 7(1): 243-248

10. Etienne, M., Ifremer and Nantes, 2005. Methods for chemical quality assessment volatile amines as criteria for chemical quality assessment sea food, https://archimer.ifremer.fr/doc/ 2005/rapport-6486.pdf (Revised at 4/9/2020).

11. Fernandes, J., Perez-Alvaez, J.A. and Fernandez-Lopez, J.A., 1997. Thiobarbituric acid test for monitoring lipid oxidation in meat. Food Chemistry, 59:345-353.

12. Gamal El-Deen, G. and El-Shamery, M. R. 2010. Studies on contamination and quality of fresh fish meats during storage. Egypt. Acad. J. Biol. Sci., 2(2): 65-74

13. Gerges, T.M., Selim, A. and Osman, M. 2016. Improvement the Shelf Life of Tilapia Fillets Stored at Chilling Condition. Benha Veterinary Medical Journal, 31(2):45-55

14. Ghannam, H. E., Talab, A.S. and Elewa, A.A., 2015. Impact of seasonal changes on the quality of water and fish from Abu Za'baal Lakes. Journal of Bioscience and Applied Research, 1(4): 192-199

15. Gonçalves, A.A., Souza, M.A. and Regis, R.C.P., 2018. Effects of different levels of food additives on weight gain, cook-related yield loss, physicochemical and sensorial quality of Nile tilapia fillets (Oreochromis niloticus). International Food Research Journal 25(5): 2068-2080

16. Gram, L. and Huss, H.H. 1996. Microbiological spoilage of fish and fish products. Int. J. Food Microbiol., 33: 121-137.

17. Hartman, P.E. 1983. Putative mutagens and carcinogens in foods. IV - Review. Malonaldehyde (malondialdehyde). https://doi.org/10.1002/em.2860050409 (Revised at 4/9/2020)

18. Hassan, M. A., Engy, F.A., Elbahy, M. and Elsherief, M.F.,2019. Evaluation of some quality indices in farmed fish from Kafr Elshiekh governorate. Benha Veterinary Medical Journal 37: 210-218

19. Howgate, P. 2009. Chapter 2. Traditional methods. In: Fishery products, quality, safety and authenticity. H. Rehbein and J. Oehlenschalger (eds.). Wiley-Blackwell, Oxford. Pp. $19-41$

20. Huss, H. H. 1995. Quality and Quality changes in fresh fish. Rome: FAO Fisheries Technical Paper, No. 348.

21. Huss, H. H., Ababouch, L. and Gram, L.2003. Assessment and Management of Seafood Safety and Quality. Rome: Food and Agriculture Organization of the United Nations. Pp 239

22. Huss, H. H., Ababouch, L. and Gram, L.2004. Assessment and management of seafood safety and quality. Rome Italy: FAO Fisheries technical paper No.444.

23. Huss, H.H. and Larsen, A. 1980. Changes in the oxidationreduction potential (Eh) of smoked and salted fish during storage. Lebensm-Wiss. Technol., 13: 40-43.

24. Jianadasa, B.K.K.K., Ginigaddarage, P.H. and Ariyawansa, S., 2014. A Comparative Quality Assessment of Five Types 
of Selected Fishes Collected from Retail Market in Sri Lanka. Am. J. Food Technol., 2(1): 21-27

25. Jinadasa, B.K.K.K., 2014. Determination of Quality of Marine Fishes Based on Total Volatile Base Nitrogen test (TVB-N). Nature and Science, 12(5): 106-111

26. Khidhir, Z.K., Murad, H.O.M. and Arif, E.D. 2013 Qualitative assessment of imported frozen fish fillets in Sulaimani markets. Iraqi J. Vet. Sci., 27(1): 49-55

27. Kilinc, B. and Cakli, S. 2004. Chemical, microbiological and sensory changes in thawed-frozen fillets of sardine (Sardina pilchardus) during marination. Food Chem. J, 88: 275-280.

28. Liu, S., Fan, W., Zhong, S., Ma, C., Li, P., Zhou, K., Peng, Z. and Zhu, M.2010. Quality evaluation of tray-packed tilapia fillets stored at $0^{\circ} \mathrm{C}$ based on sensory, microbiological, biochemical and physical attributes. African J. Biotech., 9(5): 692-701.

29. Olafsdottir, G., Martinsdottir, E., Ochlenschlager, J., Dalgaard, P., Jensen, B., Undeland, I., Mack, I.M., Henehan, G., Nielsen, J. and Nielsen, H., 1997. Methods to evaluate fish freshness in rear and industry, Trends in Food Science and Technology, 8: 258-265.
30. Onyia, L.U., Michael, K.S., Manu, J.M. and Sabo, M. 2013. Comparison of Nutrient Values of Wild and Cultured Heterobranchus bidorsalis and Clarias gariepinus. Nigerian Journal of Fisheries and Aquaculture, 1(1): 7- 12.

31. Tejada, M. and Huidobro, A., 2002. Quality of Farmed Gilthead Seabream (Sparusaurata) During Ice Storage Related to the Slaughter Method and Gutting. European Food Research Technology, 215: 1-7.

32. Teklemariam, A. D., Tessema, F. and Abayneh, T.2015. Review on Evaluation of Safety of Fish and Fish Products. Int. J. Fisheries and Aqua. Stud., 3(2): 111-117

33. Verma J.K., Srikar L.N., Sudhakara N.S, Sarma J., 1995. Effects of frozen storage on lipid freshness parameters and some functional properties of oil sardine (Sardinella longiceps) mince. Food Res. Int. 28, 87-90.

34. Yanar, Y., Celik, M. and Akamca, E., 2006. Effects of brine concentration on shelf-life of hot-smoked tilapia (Oreochromis niloticus) stored at $4^{\circ} \mathrm{C}$. Food Chem. J., 97: 244-247 